\title{
ARTICLE
}

\section{Breeding season of the South American fur seal (Arctocephalus australis, Otariidae: Carnivora): New data for establishing independent evolutionary histories?}

Temporada reproductiva del lobo fino Sudamericano (Arctocephalus australis, Otariidae: Carnivora): ¿Nuevos antecedentes para establecer historias evolutivas independientes?

\author{
Héctor J. Pavés ${ }^{1, *}$, Roberto P. Schlatter ${ }^{1, \text {,t }}$, Valentina Franco-Trecu' ${ }^{2}$, Enrique \\ Páez $^{3}$, Walter Sielfeld ${ }^{4}$, Viviana Araos ${ }^{4}$, Ricardo Giesecke ${ }^{1,5}$, \\ Luis Mario Batallés ${ }^{6}$ and Humberto Luis Cappozzo ${ }^{7}$
}

\author{
${ }^{1}$ Instituto de Ciencias Marinas y Limnológicas, Universidad Austral de Chile, Casilla 567, Valdivia, Chile \\ ${ }^{2}$ Departamento de Ecología y Evolución, Facultad de Ciencias, Universidad de la República, Iguá 4225, 11400 Montevideo, Uruguay \\ ${ }^{3}$ Departamento de Mamíferos Marinos, Dirección Nacional de Recursos Acuáticos, Ministerio de Ganadería Agricultura y Pesca, \\ Montevideo, Uruguay \\ ${ }^{4}$ Universidad Arturo Prat, Casilla 121, Iquique, Chile \\ ${ }^{5}$ Centro FONDAP de Investigación en Dinámica de Ecosistemas Marinos de Altas Latitudes (IDEAL), Chile \\ ${ }^{6}$ Ministerio de Medio Ambiente, Galicia 1133, Montevideo, Uruguay \\ ${ }^{7}$ Museo Argentino de Ciencias Naturales 'Bernardino Rivadavia', Av. Ángel Gallardo 470, C1405DJR, Buenos Aires, Argentina \\ *Afiliación actual: Bachillerato en Ciencias, Facultad de Ciencias, Universidad Santo Tomás, Osorno, Chile. hpaves@gmail.com \\ ${ }^{\text {tE} E l ~ D r . ~ S c h l a t t e r ~ f a l l e c i o ́ ~ e l ~} 13$ de mayo de 2016, Q.E.P.D.
}

\begin{abstract}
Resumen.- El lobo fino Sudamericano (SAFS) se distribuye desde Perú hasta Uruguay. Sin embargo, existe un área de 2,300 km a lo largo de la costa de Chile donde no se registran ejemplares de SAFS. A partir de comparaciones morfológicas se ha identificado la presencia de 3 formas geográficas (Peruana, Chilena austral y Atlántica), a la vez que estudios moleculares preliminares sugieren la presencia de 3 tipos genéticos distintivos (Peruana, Chilena austral y Atlántico). Sin embargo, ambas aproximaciones apoyan la existencia de 2 historias evolutivas independientes para los SAFS (Peruana, Atlántica), en cuyo caso, se podría esperar encontrar similares diferencias también en aspectos de la historias de vida de la especie entre estas poblaciones locales (e.g., en el tiempo de la estación reproductiva). En este estudio, se comparó la estación reproductiva de ejemplares del SAFS establecidas en Punta Pichalo ( $19^{\circ} 36^{\prime} \mathrm{S}$-Chile), Isla Guafo ( $43^{\circ} 33^{\prime} \mathrm{S}$-Chile), e Isla de Lobos ( $35^{\circ} 01^{\prime} \mathrm{S}$-Uruguay) con otros datos publicados para Punta San Juan ( $15^{\circ} 21^{\prime}$ S-Perú). El periodo de formación de los harenes, el periodo de pariciones y el de cópulas ocurrieron en fechas semejantes en Punta Pichalo y Punta San Juan y aproximadamente un mes más tarde en Isla Guafo e Isla de Lobos. El máximo de pariciones se registró en Isla Guafo el 15 de diciembre, en Isla de Lobos el 17 de diciembre, y en Punta Pichalo el 27 de noviembre. Estas diferencias no estuvieron relacionadas con las características demográficas, ni con las condiciones oceanográficas o con el fotoperiodo de las colonias bajo estudio, ni tampoco estaría relacionado con el efecto latitudinal sobre la fenología reproductiva. En base a los resultados, se sugiere que ciertas características de las historias de vidas pueden también ayudar a identificar especies con historias evolutivas independientes.
\end{abstract}

Palabras clave: Lobo fino, estación reproductiva, fenología reproductiva, unidades evolutivas independientes

Abstract.- The South American fur seal (SAFS) is distributed from Peru (Pacific Ocean) to Uruguay (Atlantic Ocean). However, there is a section of coastline of about $2,300 \mathrm{~km}$ along the Chilean coast where no SAFS are recorded. Based on morphological comparisons 3 geographic forms have been reported (Peruvian, South Chilean, Atlantic), whereas preliminary genetic studies suggest the presence of 3 distinct genetic types (Peruvian, South Chile, Atlantic). However, both of these approaches are support only the existence of 2 independent evolutionary histories for SAFS (Peruvian, Atlantic), in which case, we would also expect to find some differences in the species' life histories among these locals populations (e.g., in the timing of the breeding season). In this study, we compare the breeding seasons of SAFS at Punta Pichalo ( $19^{\circ} 36^{\prime} \mathrm{S}$-Chile), Isla Guafo ( $43^{\circ} 33^{\prime}$ S-Chile), and Isla de Lobos $\left(35^{\circ} 01^{\prime}\right.$ S-Uruguay) with data published for Punta San Juan $\left(15^{\circ} 21^{\prime}\right.$ S-Peru). The periods for establishing territories, pupping, and mating took place on similar dates at Isla Guafo and Isla de Lobos, but occurred about a month earlier at Punta Pichalo and Punta San Juan. Pupping peaked at Isla Guafo on 15- December, at Isla de Lobos on 17- December, and at Punta Pichalo on $27-$ November. These differences in timing were not related to demographic, oceanographic or photoperiod conditions of the breeding sites under study, neither is related with the latitudinal effects on the breeding phenology. Based on results, we suggest that certain characteristics of life history can help identify species with independent evolutionary histories.

Key words: Fur seals, breeding season, breeding phenology, evolutionary independent units 


\section{INTRODUCTION}

The South American fur seal (hereafter SAFS, Arctocephalus australis Zimmermann, 1783) ${ }^{1}$ is an otariid species with a widespread distribution along the coasts of South America, ranging from Mazorca Island (11 23 'S ) in Peru (Pacific Ocean), even though some specimens may reach lower latitudes, through Tierra del Fuego $\left(55^{\circ} 40^{\prime} \mathrm{S}\right)$ to Isla de Lobos $\left(35^{\circ} 01^{\prime} \mathrm{S}\right)$ in Uruguay (Atlantic Ocean) (Sielfeld 1983, 1999; Torres \& Contreras $1987^{2}$, Jefferson et al. 1993, Bastidas \& Rodriguez 2005). Recently was suggested that the northernmost occurrence of Arctocephalus australis in the Pacific coast is at Isla Foca $\left(5^{\circ} 12^{\prime} \mathrm{S}, 81^{\circ} 12^{\prime} \mathrm{W}\right) 765 \mathrm{~km}$ north to Mazorca in the Peruvian coast (Dra. Oliveria, pers. comm. 2015 ${ }^{3}$ ). However, this species is absent along 2,300 km of the Chilean coastline (Pacific population), from Antofagasta Region $\left(23^{\circ} \mathrm{S}\right)$ to Chiloe Island ( $43^{\circ} \mathrm{S}$ ) (Pavés 2008, Túnez et al. 2013) (Fig. $1)$. The reasons for this gap are unknown.
The widespread distribution of SAFS has motivated several morphological and genetic researches with the aim of clarify the taxonomic status of this species. Comparisons of morphometric measurements (traditional and geometric) of skull shape and size, have allowed the differentiation of 3 distinct geographic forms (Peru-North Chile, South Chile, Atlantic populations; Oliveira et al. 1999, 2008; Oliveira 2004). On the other hand, 3 well-defined clusters (Peru, South Chile-South Argentine, Uruguay populations) of this species had been identified using mitochondrial DNA analysis (Túnez et al. 2006, 2013). However, both morphological and genetic data support the existence of only 2 distinct evolutionarily significant units (ESUs) for these populations of SAFS (i.e., Peruvian, Atlantic), as proposed by Oliveira et al. (2005, 2008). An ESU is defined as a lineage demonstrating highly restricted gene flow from other such lineages within the higher organizational level of the species,

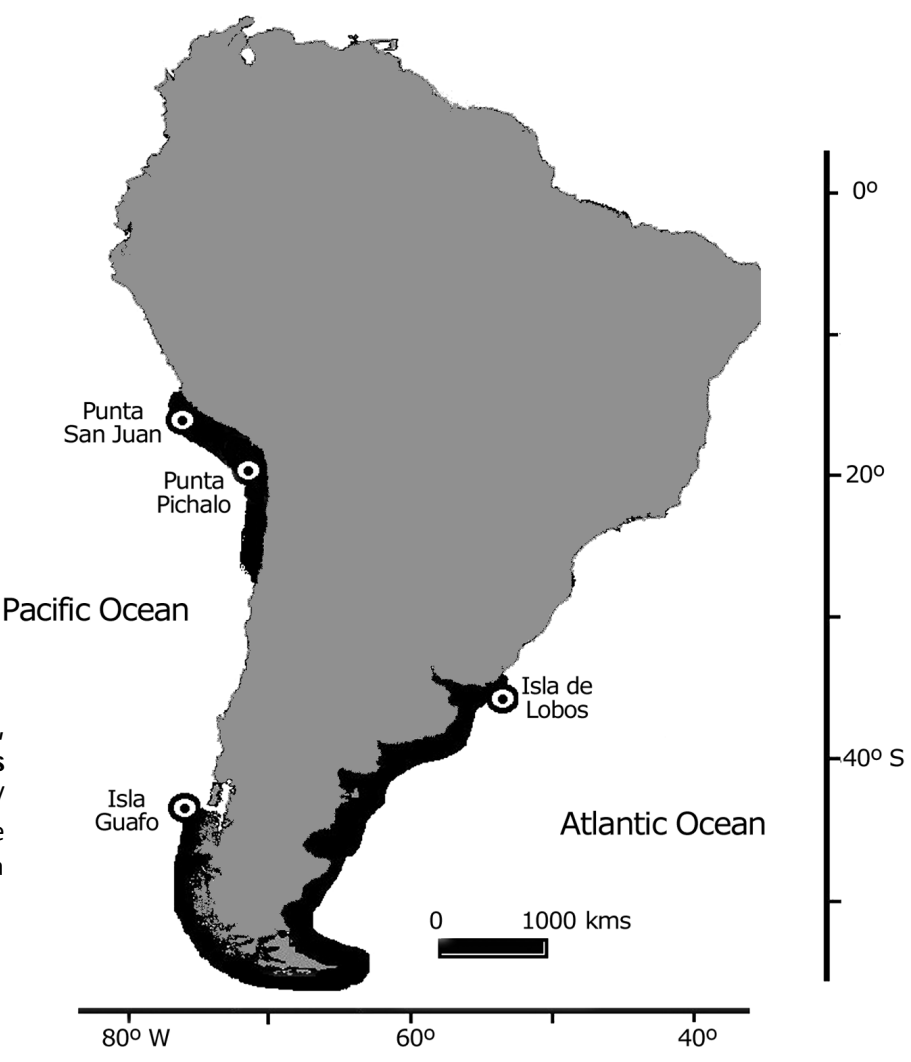

Figure 1. Geographic location of Punta Pichalo, and Isla Guafo (Chile), Isla de Lobos (Uruguay), and Punta San Juan (Peru). Dark gray areas represent the zones inhabited by Arctocephalus australis gracilis / Ubicación geográfica de Punta Pichalo e Isla Guafo (Chile), Isla de Lobos (Uruguay), y Punta San Juan (Perú). El área gris oscura representa la zona habitada por Arctocephalus australis gracilis

\footnotetext{
${ }^{1}$ Taxonomy of this species according Committee on Taxonomy. 2014. List of marine mammal species and subspecies. Society for Marine Mammalogy, www.marinemammalscience.org, consulted on (Sept 26, 2015).

${ }^{2}$ Torres J \& L Contreras. 1987. Presencia del lobo fino austral (Arctocephalus australis) en Isla Guafo, Chiloé. Informe Final, Proyecto Fondecyt 86/1461, 4 pp. <http://w1.conicyt.cl/bases/bibfon/html/6/1/1861461.html>

${ }^{3}$ Dra. Larissa Rosa de Oliveira, Laboratório de Ecologia de Mamíferos, Programa de Pós-Graduação em Biologia Diversidade e Manejo de Vida Silvestre, Universidade do Vale do Rio dos Sinos (UNISINOS), Avenida Unisinos, 950, São Leopoldo, RS, Brasil. larissaro@unisinos.br
} 
and for to probe the complete isolation between local populations imply in the ESUs, is necessary use of different molecular markers and morphological traits (Túnez et al. 2013). Therefore, if the populations of this species do have distinct evolutionarily histories and constituting different ESUs, we would also expect to find differences in their natural histories (e.g., phenology or the timing of the breeding season). Following this rationale, biologically significant differences between peak reproductive dates could have produced reproductive isolation barriers between populations, facilitating speciation (i.e., distinct breeding periods, Futuyma 1997).

Like most Otariidae, the reproductive activities of SAFS occur in spring-summer, within a short period of time known as the reproductive synchronization period (Majluf 1987, 1992; Pavés et al. 2005, Pavés \& Schlatter 2008). This period coincides with greater marine productivity and higher temperatures in coastal environments, favoring the development and survival of the offspring and ensuring the reproductive success of otariids species from year to year (Bowen 1991, Trites \& Antonelis 1994, Testa 2002, Gibbens \& Arnould 2009). During the breeding season, adult males establish territories in specific areas of the breeding sites, defending those territories from other males that arrive later. When reproductive females arrive at the established territories, the birthing (pupping) and mating periods begin. Pupping and mating are generally observed over the course of one month, with a few weeks lag between them (i.e., less than a week; Boness 1991, Bowen 1991). This phenology repeats year after year at the same time in each breeding colony (Campagna 1985, Boness 1991, Majluf 1992, Trites \& Antonelis 1994).

The paper aim to compare the breeding patterns of 3 populations of SAFS at distinct latitudes within its distribution range: two Pacific Ocean populations (Punta Pichalo-19³6’S in North Chile; Isla Guafo- $43^{\circ} \mathrm{S}$ in South Chile) and one Southwest Atlantic Ocean population (Isla de Lobos- $35^{\circ} 01^{\prime} \mathrm{S}$ in Uruguay). These data were compared with results from a Peruvian population (Punta San Juan-15²1'S; Majluf 1987, 1992; Cárdenas 2007). If the populations of this species have distinct evolutionary histories, we would expect to find differences in their breeding seasons regardless of the oceanographic conditions and photoperiod duration at the breeding colonies.

\section{MATERIALS AND METHODS}

\section{BreEding COLONIES}

Punta San Juan (Peru; $15^{\circ} 21^{\prime}$ S $; 75^{\circ} 11^{\prime}$ W; Fig. 1): is a 0.22 $\mathrm{km}^{2}$ peninsula located $500 \mathrm{~km}$ south of the city of Lima (Peru). This is a protected Guano Reserve administered by
PROABONOS, a Peruvian governmental company. The study carried out by Majluf (1987) took place in the beach site (called S3), the biggest and the most commonly used breeding site during each year for the fur seals at Punta San Juan. Two observation points were established on top of $30 \mathrm{~m}$ and on cliffs that overlook the study site which allowed observations without disturbing fur seals (Majluf 1987). Daily observations were carried out throughout the entire breeding season (1984, 1985, 1987, 1988), from early October to late December (Majluf 1992).

Punta Pichalo (North Chile; 19³6'S; 70¹4'W; Fig. 1): has been considered to be one of the most important breeding site, with the highest number of births each year for the northern Chilean population of SAFS since 1986, when El Niño Southern Oscillation (ENSO) event made fur seals to migrate from Peru to North Chile (Guerra \& Torres 1987). The Punta Pichalo breeding site is located $150 \mathrm{~km}$ north of Iquique $\left(20^{\circ} 13^{\prime} \mathrm{S}\right.$; $70^{\circ} 09^{\prime} \mathrm{W}$ ). Behavioral and census data were collected between September and March in 2001 and 2006, between 08:00 and $14: 00 \mathrm{~h}$, accumulating a total of 170 observation hours.

Isla de Lobos (Uruguay; $35^{\circ} 01^{\prime}$ S; 545'' W; Fig. 1): is located 6 nautical miles (nm) southeast of Punta del Este (34 53 ' S; $\left.56^{\circ} 09^{\prime} \mathrm{W}\right)$. Periodic observations were carried out during 3 breeding seasons: 1991 (December), 2004-2005 (November to February), and 2005-2006 (November to late January). During the first breeding season, observations were made at Las Bovedas (1991), from 6 to 22 December, between 08:00 and 18:00 h, for a total of 170 observation hours. During the 2004-2005 (27 November to 23 February) seasons, observations were made at El Muelle from 07:00 to 10:00 and from 16:00 to 19:00 h, for a total of 270 observation hours. During the 2005-2006 (14 November to 17 January) seasons, only daily censuses of territorial males and direct pup counts were made. El Muelle and La Boveda are located less than 2 kms away.

Isla Guafo (South Chile, $43^{\circ} 33^{\prime}$ 'S; $74^{\circ} 51^{\prime}$ W; Fig. 1): this is the breeding colony of SAFS with the highest annual pup production between the $18^{\circ} \mathrm{S}$ and $48^{\circ} \mathrm{S}$ (Pavés \& Schlatter 2008). Punta Weather is on Isla Guafo, $30 \mathrm{~nm}$ from the Port of Quellón $\left(43^{\circ} 07^{\prime} \mathrm{S} ; 7^{\circ} 36^{\prime} \mathrm{W}\right)$ on the southwest extreme of Chiloe Island. The two largest breeding sites on Isla Guafo, with an annual production of 1,200 pups (Pavés \& Schlatter 2008), were chosen for this study. Direct observations of groups and their breeding behavior were conducted from 08:00 to 20:00 h using binoculars. Data collection took place during 2 breeding seasons: 2004-2005 (November to February) and 2005-2006 (December to early January), resulting in $450 \mathrm{~h}$ of observations. 


\section{DEMOGRAPHY, BREEDING SEASON AND ANALYSES}

The numbers of juveniles, females, territorial males (= number of territories), pups, and mating events were registered at each site. Two or 3 detailed counts of all social age classes were carried out weekly by observers. Censuses were repeated when counts among observers differed by $10 \%$ or more (Pavés et al. 2005, Pavés \& Schlatter 2008). A territory was determined as established when a territorial male was permanently rounded by at least 2 adult females in a specific place, and the male tried continuously to group them around him. Therefore, the fluctuation of the territories was obtained from census data. Mating were registered using scan observation methods. For each breeding site, one or 2 researcher performed continuous scan for a period of 6-12 h. The number of mating was standardized in each breeding colony by the effort unit (observation hours per day). Pupping and mating dates (periods and peak) at the distinct breeding colonies were estimated using the sigmoid method described by Trites (1992), and applied by García-Aguilar \& Aurioles-Gamboa (2003), Soto et al. (2004), Pavés et al. (2005), and Pavés \& Schlatter (2008) in sea lions and fur seals. As the numbers of pups or mates increases during the breeding season in a logistic way, they can be fitted to a sigmoidal equation (Gompertz model), enabling the breeding periods (frequency curves) and peak (maximum) of each breeding season to be estimated from the daily incremental difference of each fitted Gompertz model for births and mates. The increasing number of pups and the rate of mate per hour throughout the breeding season were used to characterize the season of birth and mating by using the following equation (1): $P_{t}=A / 1+c e^{-k t} ;$ (1), where, $P_{t}$ is the accumulated number of pups per day or mating per hour of the day ' $t$ '; A is the asymptote; $c$ is the integration constant; $k$ is the fixed increase rate.

This equation was adjusted using the sum of the minimum squares to determine the distinct parameters support in the Curve Expert v1.0 program. From the adjusted logistical equation (eq. 1) we determined the relative daily increase/ decrease rate of mating and births building frequency curve for each parameter (=number pups, =number mating) (Trites 1992). By using these curves, we determined the periods in which synchronization of birth or synchronized pupping period and mating or synchronized mating period, as the period during which $90 \%$ of all births or mating occurs (Boness 1991). Moreover, the median point of the accumulated frequency curves allowed us to estimate the median birth date (i.e., births peak, pups peak or pupping peak) or median mating dates (Boness 1991). Nevertheless, these peaks were confirmed with the mathematical estimation of the average date of maximum births $\left(M_{b}\right)$ and mating $\left(M_{m}\right)$ obtained from the following equation (2): $M_{p}=$ $[-\ln (1 / c)] / k ;(2)$, where, the parameters used in equations (2) were those obtained in equation (1) (Trites 1992).

When the logistic curves were fitted for pupping or mating data for each year and location considered, an average was calculated between the sampled years to obtain the breeding phenology for each colony. Pupping patterns were successfully determined for all colonies during 2004-2005 and 2005-2006 breeding seasons. The mating periods were not fully determined for the Lobos population in the 1991 and 2004-2005 breeding seasons, but we present qualitative data to describe the general trend. This situation is related with the methods applied at Lobos site, where no observations were done between 10:00 to $16: 00 \mathrm{~h}$. In the others colonies we do not have problem to estimate the mating periods. Then, pupping and mating periods were obtained from data modeling.

\section{LOCAL CLIMATOLOGY AND ANALYSIS (CLIMATE FORCING)}

Data for monthly local climatology of sea surface temperature (SST), chlorophyll (Chl-a), and photoperiod duration were collected for the period 2002-2012 for each SAFS colony. It is necessary to mention that these local climatologically data does not apply to the breeding site Las Bovedas studied in 1991. Photoperiod durations for the 10-year period were obtained from the National Oceanic and Atmospheric Administration (NOAA) ${ }^{4}$ web site, whereas the SST and Chl- $a$ data were obtained from satellite images (4-km resolution; MODIS AQUA) between July 2002 and February 2012. Values of Chl- $a$ and SST were averaged over an area with a radius of $\sim 200 \mathrm{~km}$ around the colony; this represents the foraging area limits of reproductive females, which is less than $200 \mathrm{~km}$ for several otariids (Thompson et al. 1998, Campagna et al. 2001, Thompson et al. 2003, Page et al. 2006). For SST and Chl-a data, we obtained monthly averages of 4-micron night products from the Giovanni Website ${ }^{5}$ (Acker \& Leptoukh 2007). These data were later re-analyzed to perform climatology analyses for all the study areas. In this research, the data for describe the breeding phenology in SAFS was not collected during strong ENSO periods (<www.shoa.cl>).

\section{STATistical analysis}

Statistical analyzes were performed using STATISTICA 7.0 $(\text { Statsoft, Inc })^{6}$. Normality assumptions were evaluated with the Shapiro-Wilk (W) test and the homogeneity of variance of the

\footnotetext{
${ }^{4}<$ www.srrb.noaa.gov/highlights/sunrise/NOAA_Solar_Calculations_year.xls>

${ }^{5}<$ http://gdata1.sci.gsfc.nasa.gov/daac-bin/G3/gui.cgi?instance_id=ocean_month>

${ }^{6}$ Statsoft. 2001. Statistica. Data analysis software system, Version 8. <www.statsoft.com>
} 
data with Levene's test. When these conditions were not met or their transformation was not achieved, non-parametric tests were used. The ANOVA and Kruskal-Wallis $(\mathrm{H})$ tests were used to determine differences in the type of distribution of the reproductive patterns between breeding colonies (i.e., ANOVA for the number of territorial male or territories, and KruskalWallis for the birth, and mating data). The results of the KruskalWallis test were analyzed using a multiple comparison test (z) for non-parametric data in order to identify the variables that best explained the difference, or to determine the breeding colony that explained the difference (Zar 1999; Statsoft Inc. 20016). Median tests were applied to determine differences in the dates of reproductive phenology among breeding colonies. The Median test is a 'crude' version of the Kruskal-Wallis ANOVA in that it frames the computation in terms of a contingency table. Specifically, STATISTICA will simply count the number of cases in each sample that fall above or below the common median, and compute the Chi-square value for the resulting $2 \mathrm{x} \mathrm{k}$ contingency table. Under the null hypothesis (all samples come from populations with identical medians), we expect approximately $50 \%$ of all cases in each sample to fall above (or below) the common median. The mean \pm standard deviation of each demographic value was calculated. Pearson correlations (r) of monthly means were performed using annual SST and Chl- $a$ for the study sites (breeding colonies).

\section{Results}

\section{DEMOGRAPHIC DATA}

Punta Pichalo (northern Chile): During 2001-2006, the maximum number of fur seals counted was of 747.2 \pm 194.5 animals (mean \pm standard deviation, SD) ranging between 570 and 974 . Of the 747 animals counted, $7.3 \%$ were adults males $($ range $=35-81), 71.7 \%$ were females and juveniles $($ range $=$ 416-701), and $21.0 \%$ were pups (range $=108-206$ ).

Isla de Lobos (Uruguay): During 1990-1991, the maximum number of fur seal was $511.6 \pm 79.8$ individuals (range $=479$ 615 ). Of 511 animals counted, $5.1 \%$ were adults males (range= 23-29), 45.6\% were females and juveniles (range $=188-265$ ), and $49.4 \%$ were pups (range $=135-361$ ). During 2004-2006 breeding seasons, maximum average number of SAFS was $691.0 \pm 48.1$ animals (range $=657-725$ ). The $5.6 \%$ of these fur seals were adults males (range $=36-41$ ), $47.6 \%$ were females and juveniles (range $=308-350$ ), and $46.8 \%$ were pups (range= 308-339).

Isla Guafo-Punta Weather (southern Chile): The maximum number of fur seals counted at Guafo during the two breeding seasons $(2004-2006)$ was $2,969.3 \pm 257.7$ (range $=2,787$ -
3,152 ). The $8.0 \%$ of these fur seals were adults males (range $=$ 221-256), 53.0\% were females and juveniles (range $=1568$ 1577 ), and $39.0 \%$ were pups (range $=998-1319)$.

\section{BREEDING SEASON}

At Punta Pichalo, territorial males were observed from the third week of September until the second week of March. Most territories ( 40 territories) were established between the fourth week of November and third week of December (Table 1). The maximum number of territorial males was recorded in the second week of December. In the Peruvian population (Punta San Juan), during the $1984-1985$ breeding season, $85 \%$ of the territories were identified between 25 November and 14 December, with a maximum registered on 7 December (Table 1). The territorial males at Punta San Juan were recorded over 3 months (October-December) (Majluf 1987, Cárdenas 2007) (Table 1).

At Lobos, during the beginning of the 2004-2005 sampling season (third week of November), around $50 \%$ of the maximum number of territories had been occupied, leading to the conclusion that the adults males had begun to occupy the breeding areas some weeks earlier. Most territories were abandoned in late January, although some adult males continued to defending territories until the first week of February. Most territories were held between early and mid-December, with a daily average of $5.8 \pm 0.5$ to $32.3 \pm 2.0$ territorial males from November 2004 to February 2005 (Table 1). The maximum number of territories within the study area $(n=36$ for 20042005 ) occurred during the fourth week of December, and $90 \%$ of territorial males protected their territories between the third and fourth weeks of that month (Table 1). During the 1991 season, the number of territorial males was relatively constant, with 28 to 36 territorial males (average $33.7 \pm 0.9$ ) between the first and third weeks of December (Table 1).

At Isla Guafo, the first territories were established during the first week of November and the last territory was established during the first week of February. Most territories were established between late November and early December, with a daily average for the 2 seasons of $183.2 \pm 35.8$ territorial males. The maximum number of territories $(n=220,2004-2005$; $n=121,2005-2006)$ was recorded during the third week of December, and $90 \%$ of these were observed in the second week of December (Table 1).

Variation in the date of establishment of the territories differed significantly between breeding colonies (KruskalWallis test: $H_{2,289}=34.41, P<0.05$; Table 1, Fig. 2a). Punta Pichalo differed significantly from the rest of the colonies (Pichalo vs. Lobos: $z=5.45, P<0.05$; Pichalo vs. Guafo: $z=$ 
Table 1. Dates for reproductive patterns of South American fur seals at Punta San Juan, Peru; Punta Pichalo and Isla Guafo, Chile; and Isla de Lobos, Uruguay, during the breeding seasons: 2001-2006 (Pichalo), 2004-2005 and 2005-2006 (Lobos, Guafo). EM =El M uelle; LB=Las Bovedas / Fechas de los patrones reproductivos del lobo fino sudamericano en Punta San Juan, Perú; Punta Pichalo e Isla Guafo, Chile; e Isla de Lobos, Uruguay, durante las temporadas reproductivas: 2001-2006 (Pichalo), 2004-2005 y 2005-2006 (Lobos, Guafo). EM= El Muelle; LB= Las Bovedas

\begin{tabular}{|c|c|c|c|c|}
\hline & $\begin{array}{l}\text { Punta San Juan }^{1} \\
\text { (Peru) } \\
15^{\circ} 21^{\prime} \mathrm{S} ; 75^{\circ} 11^{\prime} \mathrm{W}\end{array}$ & $\begin{array}{c}\text { Punta Pichalo } \\
\text { (Pichalo, Northern } \\
\text { Chile) } \\
\text { 19³6'S; } 70^{\circ} 14^{\prime} \mathrm{W} \\
\end{array}$ & $\begin{array}{l}\text { Isla de Lobos } \\
\text { (Lobos, Uruguay) } \\
35^{\circ} 01^{\prime} \mathrm{S} ; 54^{\circ} 52^{\prime} \mathrm{W}\end{array}$ & 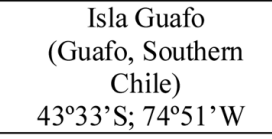 \\
\hline Last Territorial Male & $4^{\text {th }}$ week Dec. & $2^{\text {nd }}$ week March & $1^{\text {st }}$ week Feb. & $1^{\text {st }}$ week Feb. \\
\hline Maximum number of territories & $1^{\text {st }}$ week Dec. & $2^{\text {nd }}$ week Dec. & $4^{\text {th }}$ week Dec. & $3^{\text {rd }}$ week Dec. \\
\hline $90 \%$ Territorial Males & 25 Nov. - 14 Dec. $^{2}$ & 27 Nov.- 15 Dec. & $3^{\text {nd }}$ and $4^{\text {th }}$ of Dec, & $2^{\text {nd }}$ week Dec. \\
\hline First birth & $\begin{array}{l}5 \text { Oct. (1984) } 9 \text { Sept. (1985), } \\
9 \text { Oct. (2005) }\end{array}$ & 20 Sept. 2001 & 16 Nov.(EM) & 11 Nov. \\
\hline Last birth & $\begin{array}{l}29 \text { Nov. (1984), } 12 \text { Dec. (1985), } \\
15 \text { Dec. (2004), } 9 \text { Dec. (2005) }\end{array}$ & 18 Dec. & 7 Jan. (EM) & 3 Jan. \\
\hline Pupping peak & $\begin{array}{l}11 \text { Nov. (1984), } 19 \text { Nov. (1985), } \\
3^{\text {rd }} \text { week of Nov. (2005) }\end{array}$ & 27 Nov. 2001 & $\begin{array}{l}17 \text { Dec.(EM) } \\
10 \text { Dec. (LB) }\end{array}$ & 15 Dec. \\
\hline $\begin{array}{l}\text { Birth synchronization } \\
(90 \%)\end{array}$ & $\begin{array}{l}\text { 1-3 Nov. }-1-4 \text { Dec. }(1984,40 \text { days }) \text {, } \\
4^{\text {th }} \text { week of Nov. }-1^{\text {st }} \text { week of Dec. } \\
(2005)\end{array}$ & Nov.-Dec. & $\begin{array}{l}27 \text { Nov. - } 5 \text { Jan. } \\
(40 \text { days })(\mathrm{EM})\end{array}$ & $\begin{array}{l}1-30 \text { Dec. } \\
\text { (30 days) }\end{array}$ \\
\hline First mating & 20 Oct. (2004) & 20 Oct. 2001 & 25 Nov. & 12 Nov. \\
\hline Last mating & 15 Dec. $(2005)$ & 13 Dec. 2001 & 13 Jan. & 24 Jan. \\
\hline Mating peak & $3^{\text {rd }}$ week Nov. & Not observed & 20 Dec. $^{3}$ & 20 Dec. \\
\hline Mating synchronization $(90 \%)$ & $1^{\text {st }}$ week Dec. - $2^{\text {nd }}$ week Dec. (2005) & Not observed & $\begin{array}{l}4 \text { Dec.- } 3 \text { Jan (31 } \\
\text { days) })^{3}\end{array}$ & 5 Dec.-3 Jan. (30 days) \\
\hline
\end{tabular}

${ }^{1}$ Majluf (1987, 1992); Cárdenas (2007). ${ }^{2} 85 \%$ Territorial Males. ${ }^{3}$ Franco-Trecu et al. (2014)

$3.69 P<0.05)$ while Isla Guafo and Isla de Lobos did not show any statistical differences $(z=1.81, P=0.21)$. In other words, territories were established on similar dates at the Guafo and Lobos breeding colonies, but at Punta Pichalo and Punta San Juan, they were established one month earlier (see overlap of the median, and $25-75 \%$ percentiles; Fig. 2 a).

\section{THE PUPPING SEASON}

The pupping season at Punta Pichalo lasted from September to December, with the pupping peak on 27 November (Table 1). For the Peruvian population (San Juan), the synchronized pupping period for the 1984-1989 seasons lasted 40 days and took place between 11 and 19 November (Majluf 1987, 1992) (Table 1).

The birth synchronization period at Isla de Lobos (El Muelle study area), was estimated between the fourth week of November and the first week of January, lasting 40 days during 2004-2006 breeding seasons (Table 1), with maximum pupping on 17 December. In this same island but at Las Bovedas breeding site, the pupping peak was estimated to be 10 December, and the birth synchronization period occurred throughout December 1991 (Table 1). At Isla Guafo occurred between the first and the fourth weeks of December, lasting 30 days; pupping peaked on 15 December.
A comparison of our results (Isla Guafo, Isla de Lobos) with Majluf's data (1992) revealed significant differences in the birth synchronization periods between these populations (KruskalWallis test: $H_{2,286}=184.23, P<0.05$; Fig. 2). No such difference occurred between Isla de Lobos and Isla Guafo (multiple comparison, $z=0.904, P>0.05$; Fig. 2b, c), suggesting that these breeding colonies had similar pupping periods, but both colonies differed from those at Punta Pichalo and Punta San Juan (see overlap of the median, and $25-75 \%$ percentiles; Fig. 2b; Table 1).

\section{The Mating PERIOD}

At Punta Pichalo, the mating period occurred between November and December. Mating activity was first recorded on 20 October and continued until 13 December. At Punta San Juan, the mating period was between October and December, with peak mating activity in November (Cárdenas 2007).

The synchronized mating period for the population at Isla de Lobos was not possible to determine during our study, but mating was observed from the last week of November to the second week of January (Table 1). In a recent research, FrancoTrecu et al. (2014) found that the mating's synchronization period at Isla Lobos ('El Muelle') lasted 31 days (i.e., 4 December 2010 to 3 January 2011) with the peak mating date 
a)



b)

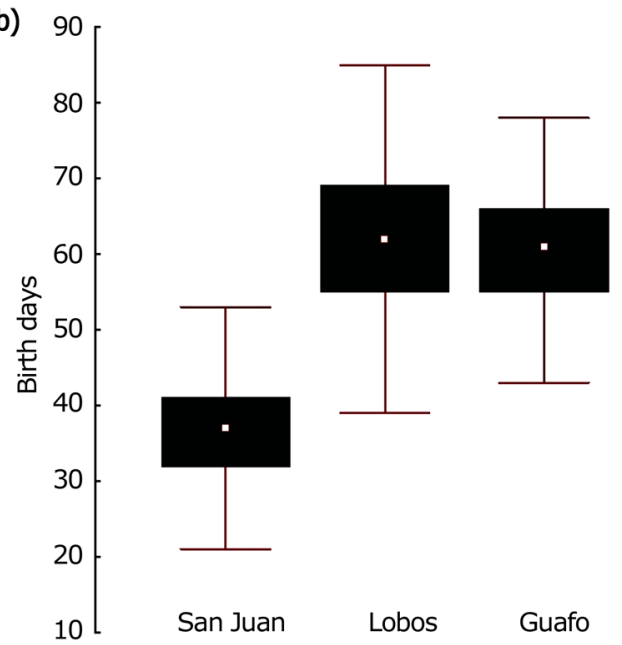

c)

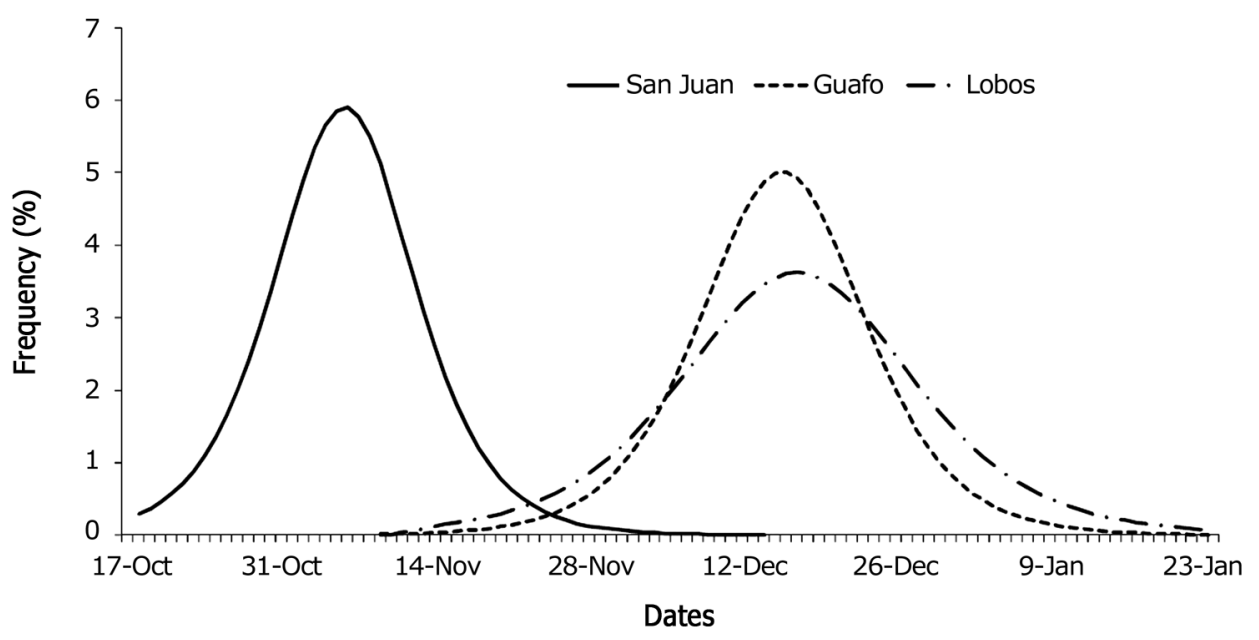

Figure 2. Variations in territorial male establishment and birth dates at 4 South American fur seal breeding colonies. In: a) Dates of male territory establishment during the breeding season obtained from census data; b) Timing of births throughout the breeding season obtained from data modeling (day 10= 10 Oct); and c) Pupping season at the 3 colonies obtained from data modeling. Data for San Juan were obtained from Majluf (1992); whereas for Pichalo, Guafo, and Lobos data come from this study / Fluctuación en el período de establecimiento de los territorios y fechas de pariciones de 4 agrupaciones reproductivas del lobo fino Sudamericano. En: a) Período de establecimiento de los machos territoriales durante la estación reproductiva obtenida desde los datos censales; b) Período de partos obtenida de los datos modelados (día 10=10 de oct); y c) Variaciones de las fechas de pariciones a los largo de la estación reproductiva en 3 colonias, obtenida desde los datos modelados. Los datos de San Juan fueron obtenidos de Majluf (1992); mientras que para Pichalo, Guafo, y Lobos, los datos fueron obtenidos del presente estudio

on 20 December 2010. Thus, the mating period showed a similar trend to the pupping period (Table 1). At Isla Guafo lasted 30 days and took place between the first week of December and the first week of January, with the peak mating date on 20 December.

Even though it was not possible to determine the exact mating peaks or its synchronization period at Isla de Lobos and Punta
Pichalo, we assumed that these would follow the trends in the pupping peak, but with a lag of 6 to 8 days as observed in at least 12 Otariidae species, included the SAFS (Riedman 1990, Boness 1991). Thus, the mating period (maximum date) at Isla de Lobos occur within the same month as at Isla Guafo (December) but one month later than at Punta Pichalo and Punta San Juan. 
Territorial establishment, pupping, and mating periods were observed on similar dates at Isla Guafo and Isla de Lobos breeding colonies, but occurred earlier and lasted longer at Punta Pichalo and Punta San Juan (Table 1). This lag was not related to changes in latitudinal differences of photoperiod duration since the sunlight duration decreased to $12 \mathrm{~h}$ per day in the same month for all sites considered (March, Fig. 3). Nor was the observed lag in breeding season among sites related to changes in latitudinal differences in SST since all sites displayed the same temperature pattern (Pearson $P<0.001, r>0.98$; Fig. 4). The trend in surface chlorophyll, used here as an index of local productivity, differed from that of SST. The only two sites where similar and significant Chl- $a$ climatology was observed was between Punta San Juan and Isla Guafo ( $r=0.64, P=0.02$, $n=12$ ), which coincided with the sites with the greatest distance between them. These 2 sites showed strong differences in breeding phenology (see results). In contrast, the two study sites nearest each other (Punta Pichalo and Isla San Juan) showed distinct Chl- $a$ climatologies $(r=0.41, P=0.18, n=12)$. Trends in Chl-concentrations were similar at both sites from January to July, with the highest Chl- $a$ concentrations occurring in austral spring and summer (Nov-Mar), then gradually decreasing through autumn (Mar-Jun). Minimal values were recorded in winter (Jun-Aug), coinciding with the lowest temperatures. However, unlike San Juan, Chl- $a$ at Punta Pichalo did not increase from winter to spring but remained relatively stable and even decreased until austral summer. We must remember that Punta Pichalo and Isla San Juan had similar trends in their breeding phenology (this study). On the other hand, seasonality at Isla de Lobos was slight, with relatively low Chl- $a$ values

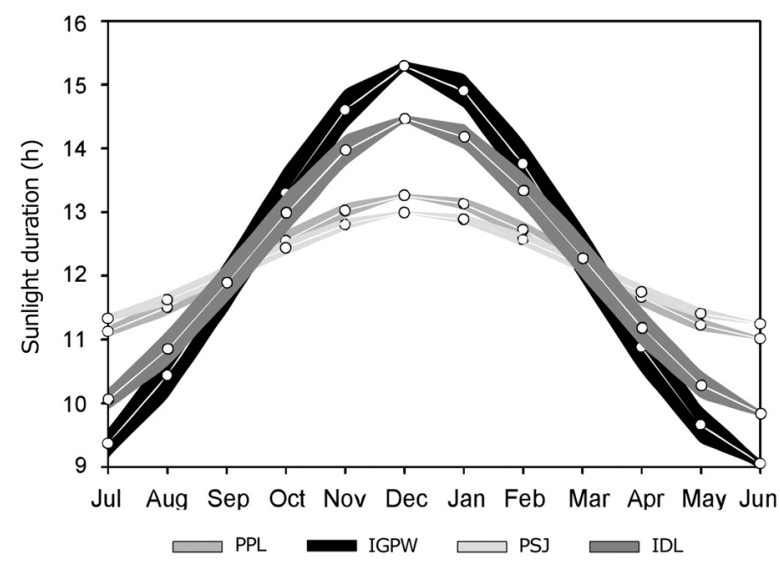

Figure 3. Annual variation of photoperiod duration at the 4 sampling sites included in this study. Mean values and standard errors of $\sim 10$ years of monthly data (2002-2012) were obtained from NOAA (<www.srrb.noaa.gov>) / Variación anual de la duración del fotoperiodo de las 4 colonias relevadas en este estudio. Los valores promedio y sus errores estándar fueron obtenidos de datos mensuales de 10 años (2002-2012) de la NOAA (<www.srrb.noaa.gov>) throughout the year $\left(<3 \mathrm{mg} \mathrm{Chl}-a \mathrm{~L}^{-1}\right)$ that increased in austral spring. The latter trend was the opposite to that recorded at Punta Pichalo, the closest latitudinal sampling site $(r=-0.64, P$ $=0.02, n=12$ ). Thus, neither latitudinal temperature trends nor local productivity (herein, Chl-a) seem to explain the changes in the breeding season at Punta San Juan, Punta Pichalo, Isla de Lobos, and Isla Guafo.

\section{Discussion}

Despite of the lag of about one month between reproductive synchronization of Guafo-Punta Lobos Island and Punta PichaloPunta San Juan, the reproductive phenology at each of these sites, is highly consistent year after year. This condition is common in other Otariidae and Phocidae demonstrating that there is stability within breeding traits of different population of a species when the environmental conditions are stable. Therefore, the phenology observed in the present time could help us to understand or estimate the phenology for the past 5 or 10 years ago (Campagna 1985, Duck 1990, Boness 1991, Majluf 1992, Trites 1992, Trites \& Antonelis 1994, Boyd 1996, Pitcher et al. 2001, García-Aguilar \& Aurioles-Gamboa 2003).

Interannual variability in the breeding phenology between populations could be due to demography (age structure), physiology (embryonic implantation period), nutritional state (female nutritional condition), and climate forcing (photoperiod, air and water temperature, marine productivity) (see for more details Ims 1990, Vila 1991, Trites 1992, Campagna et al. 1993, Temte 1993, 1994; Boyd 1996, Costa \& Gales 2003, Soto et al. 2004). Nevertheless, the populations studied herein had similar demographic characteristics, age structures, as well as sea surface temperature, and Chl- $a$ climatology (see Results). Therefore, none of these factors could explain the asynchronous breeding season of the SAFS recorded in our research between the Peruvian - North Chile, and South Chile - Uruguayan populations (with one-month lag in the maxima).

As other southern Otariidae, the reproductive activities of SAFS occur in spring-summer (i.e., late November to early January; Campagna 1985, Majluf 1992, Pavés et al. 2005), coinciding with increased productivity and higher temperatures in the coastal environments, which favor the development and survival of the offspring and presumably enhances the reproductive success (Majluf 1987, Bowen 1991, Trites \& Antonelis 1994, Testa 2002, Pavés et al. 2005, Gibbens \& Arnould 2009). Riedman (1990) and Boness (1991) analyzed the seasonality and reproductive synchrony of Otariidae by using latitude todescribe the relationship between climatic seasonality, food availability, and the reproductive periods of these otariids species. Species with non-seasonal, non-annual reproductive 



Figure 4. Annual climatology of sea surface temperature (SST; ${ }^{\circ} \mathrm{C}$ ) and $\mathrm{Chl}-\mathrm{a}\left(\mathrm{mg} \mathrm{m}^{-3}\right)$ at the 4 sampling sites included in this study. Mean values (white dots) and standard errors (black fill) of $\sim 10$ years of monthly data (Jul. 2002-Feb. 2012) were obtained from MODIS AQUA satellite. Punta San Juan= San Juan; Punta Pichalo= Pichalo; Isla de Lobos= Lobos; Isla Guafo=Guafo / Climatología anual de la temperatura superficial del mar (SST; ${ }^{\circ} \mathrm{C}$ ) y la $\mathrm{Chl}$-a $\left(\mathrm{mg} \mathrm{m}^{-3}\right)$ de los 4 sitios muestreados e incluidos en este estudio. Los valores promedios (puntos blancos) y su error estándar (barras negras) de 10 años de datos mensuales (Jul. 2002-Feb. 2012) fueron obtenidos del satélite MODIS AQUA. Punta San Juan= San Juan; Punta Pichalo= Pichalo; Isla de Lobos= Lobos; Isla Guafo= Guafo 
cycles and non-synchronized reproductive events were expected to inhabit environments with lower or no climatic seasonality, low productivity, and/or food resources of low energetic quality. For example, Australian sea lions [Neophoca cinerea (Péron 1816)] have a reproductive cycle of approximately 18 months (Higgins 1993, Costa \& Gales 2003), and the Mediterranean monk seal (Monachus monachus, Hermann, 1779) has births throughout the year (Pastor \& Aguilar 2003), conditions thought to be related with the specialized diet on low density prey, low productivity and seasonality observed between their distribution area (Higgins 1993, Costa \& Gales 2003, Pastor \& Aguilar 2003, Goldsworthy et al. 2009).

The relationship between latitude and breeding synchrony had been observed in both Otariidae and Phocidae, including: Mirounga leonina (Linnaeus, 1758) by Campagna et al. (1993), Pagophilus groenlandicus (Erxleben, 1777) by Stenson et al. (1993), Zalophus californianus (Lesson, 1828), and Phoca vitulina (Linnaeus, 1758) by Temte (1993), Phoca vitulina vitulina (Linnaeus, 1758), and Phoca vitulina richardsi (Gray, 1864) by Temte (1994), Arctocephalus forsteri (Lesson, 1828) by Goldsworthy \& Shaughnessy (1994), Eumetopias jubatus (Schreber, 1776) by Pitcher et al. (2001), and Z. californianus by García-Aguilar \& AuriolesGamboa (2003). The SAFS should constitute an example of the relationship between latitude and breeding season described by Boness (1991) due to the species' wide geographical range, which, though fragmented, clearly establishes populations within temperate climates, where other fur seals species are also found (Duck 1990). Despite differences in the breeding seasons of the populations studied here, the overall results do not agree with the trend reported by Boness (1991). The differences of about one month between breeding seasons at Punta PichaloPunta San Juan and Isla Guafo-Isla de Lobos are not related to a latitudinal effect, but this effect described by Boness (1991) is observed between the breeding seasons at Isla Guafo and Isla de Lobos. Birth synchronization lasts longer at Isla de Lobos than Isla Guafo, and pupping peaks earlier at Isla Guafo than Isla de Lobos, as expected given the latitudinal effect reported by Boness (1991) (Table 1, Fig. 2) and observations for other species (Campagna 1985, García-Aguilar \& AuriolesGamboa 2003).

It is still unknown if differences in breeding phenology recorded at Punta Pichalo, Punta San Juan, Isla Guafo, and Isla de Lobos have implications to generate reproductive isolation barriers and the establishment of a new species (Futuyma 1997). An extended lag in the breeding season between populations could prevent genetic flow and, consequently, produce a phylogenetic separation of the populations. A three-day lag between peak of mating within the same population during different years or between distinct and distant populations (e.g., Lobos vs. Guafo) may not generate reproductive barriers, however, a lag of approximately one month may have much greater reproductive significance.

The breeding patterns of the populations from Punta Pichalo (northern Chile) and Punta San Juan (Peru) differed from those Isla Guafo (southern Chile) and Isla de Lobos (Uruguay) similar pattern to the situation reported with morphological and genetic data (Oliveira 2004, Túnez et al. 2006, Oliveira et al. 2008). Guerra \& Torres (1987) noted that the Northern Chilean population (Pichalo) was derived from the Peruvian population, which was only observed after the 1982 ENSO, when SAFS migrations were observed from the southern Peruvian coast to the northern Chilean coast.

By comparing morphological characteristics, Oliveira et al. (1999, 2008), and Oliveira (2004) were able to clearly differentiate 3 geographic forms of SAFS in South America: Peru-North Chile (form 1), South Chile (Magellan channels) (form 2), and Atlantic (Lobos) (form 3). Genetic studies, revealed 3 clusters for this species (Peruvian, South Chile, and Atlantic populations). With both studies was possible to determine the existence of two ESUs, where the morphological and genetic data could support the isolation between Peruvian and Atlantic population. Unfortunately, this later study did not include any genetic information from the southern Chile population (Túnez et al. 2006, Oliveira et al. 2008). Nevertheless, Túnez et al. (2013) using only one type of molecular marker identified 2 conservation unit (South ChileSouth Argentine and Uruguay population), recommending the use others molecular markers to establish the existence of others ESUs. Thus both, genetic and morphological scenario supports the existence of two distinct evolutionarily histories in SAFS, one for Peruvian population, and other for the Atlantic population. This coupled with the existence of premating isolation mechanism - both spatial ( 2,300 km long gap off the Chilean coast) and temporal (difference in breeding phenology; this study) - could lead to the differentiation of at least 2 evolutionarily independent units of SAFS (Peru-Northern Chile, Southern Chile-Atlantic) as proposed by Oliveira et al. (2005, 2008) and Oliveira \& Brownell (2014). Recently, others authors have postulated the idea that both units could be consistent with the existence of 2 subspecies, one for Peruvian and north Chilean population, and other South Chile and Atlantic population (Berta $\&$ Churchill, 2012). Then, the results of breeding phenology found here agree with the previous morphological and genetic evidence for the species (Oliveira et al. 1999, 2008; Oliveira 2004; Túnez et al. 2006, Oliveira et al. 2008). Thus, our approach, with its faults and successes, could be help to shed 
some light into the existence of independent evolutionarily histories reported for SAFS populations (Túnez et al. 2006, Oliveira et al. 2008, Oliveira \& Brownell 2014), constituting new information with which to evaluate the taxonomic status of this species in South America. However, more conclusive results could be obtained by including the breeding colonies located in the southernmost part of South America, together with a simultaneous sampling effort of different breeding colonies along South America during non-ENSO conditions; situation which would indeed imply a huge international logistical and financial effort.

\section{ACKNOWLedGMents}

We thank Dr. Juan Ignacio Túnez, Dr. Paulo Corti, M.Sc. Alfredo Lebas, Dr. Larissa Oliveira, and M.Sc. Susana Cárdenas for providing helpful comments on this manuscript, and Shawn Booth at the UBC Fisheries Centre and Danielle Barriga for editing the manuscript prior to submission. We would like to acknowledge support at Isla Guafo (2003-2005) from Claudio Vera, Diego Miranda, Carola Vaccaro, Paula Antileo (UACh), and Sabrina Riveron (Universidad de la República del Uruguay). Financial support was provided by the Institute of Zoology-Universidad Austral de Chile (UACH), Dirección de Investigación y Desarrollo of UACH (DID-D-2004-7/D2005-15/UACh S-2013-19), Dr. Cheryl Baduini (The Claremont College, California, USA), and The Society for Marine Mammalogy Small Grants-in-Aid Award 05. The support provided by the Armada de Chile, Gobernador Marítimo of the Lagos Región, and the staff at the Guafo Lighthouse is also appreciated. At Isla de Lobos, we would like to thank Fabian Perez and Gladys Enrich (1991), Rosina Frau, and personnel of the DI.NA.R.A, Malo, Olivera, and Veiga for their assistance during 2004-2005. Financial support was also provided by the Consejo Nacional de Investigaciones Científicas y Técnicas (CONICET) of Argentina (Project PIP02193); Secretaría de Ciencia y Tecnología de Argentina; the Industria Lobera y Pesquera del Estado de Uruguay in 19901991; and I. Trecu and S. Franco and the General Direction of DI.NA.R.A during the 2004-2005 campaign. The financial support provided from D.I.N.A.R.A during the research carried out in 1991, and the logistical support provided by Bettina Tassino during 2004-2005 are also greatly appreciated. The field activities complied with the current laws of the countries in which they were performed. This work was carried out with permission from the Sub-secretary of Fisheries- Chile (SUBPESCA). HJP was supported by BECASCHILE Postdoctorate Program 2010, the Fisheries Centre of University of British Columbia (UBC), Vancouver, Canada, and the Postdoctorate Program 2011 - FONDECYT No. 3120100.
We would like to acknowledge Raúl Vaz-Ferreira (1918-2006) from Uruguay, who provided valuable early ecological information on neotropical fur seals and sea lions and inspired many young researchers. In memory and acknowledge to the work done by Dr. Roberto Schlatter (1944 - 2016), a scientist concerned about the preservation of nature and wildlife of Chile.

\section{LITERATURE CITED}

Acker J \& G Leptoukh. 2007. Online analysis enhances use of NASA Earth science data. EOS. Transactions of the American Geophysical Union 88(2): 14-17.

Bastidas R \& D Rodriguez. 2005. Marine mammals of Patagonia and Antarctica, 207 pp. Vazquez Mazzini Editores, Buenos Aires.

Berta A \& M Churchill. 2012. Pinniped taxonomy: review of currently recognized species and subspecies, and evidence used for their description. Mammal Review 42(3): 207-234.

Boness D. 1991. Determinants of mating system in the Otariidae (Pinipedia). In: Renouf D (ed). Behaviour of Pinniipeds, pp. 1-35. Chapman and Hall, New York.

Bowen W. 1991. Behavioural ecology of pinniped neonates. In: Renouf D (ed). Behaviour of Pinniipeds, pp. 66-128. Chapman and Hall, New York.

Boyd I. 1996. Individual variation in the duration of pregnancy and birth date in Antarctic fur seals: the role of environment, age, and sex of fetus. Journal of Mammalogy 77(1): 124133.

Campagna C. 1985. The breeding cycle of the Southern sea lion (Otaria byronia). Marine Mammals Science 1(3): 210218.

Campagna C, M Lewis \& R Baldi. 1993. Breeding biology of southern Elephant Seals in Patagonia. Marine Mammals Science 9(1): 34-37.

Campagna C, R Werner, W Karesh, M Marín, F Koontz, R Cook \& C Koontz 2001. Movements and location at sea of South American sea lions (Otaria flavescens). Journal of Zoology, London 257: 205-220.

Cárdenas S. 2007. Preferencia de uso de sitios para pariciones por hembras de Arctocephalus australis (Zimmermann 1783) en la Reserva Guanera Punta San Juan, Perú. Tesis de Licenciado en Ciencias, mención en Biología, Universidad Peruana Cayetano Heredia, Lima, 79 pp.

Costa D \& N Gales. 2003. Energetic of a benthic diver: seasonal foraging ecology of the Australian sea lion, Neophoca cinerea. Ecological Monographs 73(1): 27-43.

Duck D. 1990. Annual variation in the timing of reproduction in Antarctic fur seals, Arctocephalus gazella, at Bird Island, South Georgia. Journal of Zoology, London 222: 103-116.

Franco-Trecu V, P Costa, Y Schramm, B Tassino \& P Inchausti. 2014. Sex on the rocks: reproductive tactics and breeding success of South American fur seal males. Behavioral Ecology 25(6): 1513-1523. 
Futuyma D. 1997. Evolutionary biology, 702 pp. Sinauer Associates, Sunderland.

García-Aguilar M \& D Aurioles-Gamboa. 2003. Breeding season of the California sea lion (Zalophus californianus) in Gulf of California, México. Aquatic Mammals 29(1): 6776.

Gibbens J \& JPY Arnould. 2009. Interannual variation in pup production and the timing of breeding in benthic foraging Australian fur seals. Marine Mammal Science 25(3): 573587.

Goldsworthy S \& P Shaughnessy. 1994. Breeding biology and Haul-out pattern of the New Zealand Fur Seal, Arctocephalus forsteri, at Cape Gantheaume, South Australia. Wildlife Research 21: 365-376.

Goldsworthy S, J McKenzie, P Shaughnessy, R McIntosh, B Page \& R Campbell. 2009. An update of the report: Understanding the impediments to the growth of Australian sea lion populations. Report to the Department of the Environment, Water, Heritage and the Arts. SARDI Aquatic Sciences Publication Number F2008/00847- 1. SARDI Research Report Series 356: 1-175.

Guerra C \& D Torres. 1987. Presence of South American fur seal, Arctcephalus australis, in northern Chile. In: Croxall J \& R Gentry (eds). Status, biology and ecology of Fur Seals, pp. 169-176. Proceedings of an International Symposium and Workshop, Cambridge.

Higgins L. 1993. The nonanual, nonseasonal breeding cycle of the Australian sea lion, Neophoca cinerea. Journal of Mammalogy 74(2): 270-274.

Ims R. 1990. The ecology and evolution of reproductive synchrony. Tree 5(5): 135-140.

Jefferson TA, S Leatherwood \& MA Webber. 1993. FAO species identification guide. Marine mammals of the world, 320 pp. FAO. Rome.

Majluf P. 1987. Reproductive ecology of females South American fur seals at Punta san Juan, Peru. PhD Thesis, University of Cambridge, Cambridge, $126 \mathrm{pp}$.

Majluf P. 1992. Timing of births and ju venile mortality in South American fur seal in Perú. Journal of Zoology 227: 367-383.

Oliveira L. 2004. Variacao geográfica do lobo-marinho sulamericano, Arctocephalus australis (Zimmermann, 1783) com base em dados morfológicos e moleculares. PhD Thesis, Universidade de Sao Paulo, Sao Paulo, 217 pp.

Oliveira L \& R Brownell. 2014. Taxonomic status of two subspecies of South American fur seals: Arctocephalus australis australis vs. A. a. gracilis. Marine Mammal Science 30(3): 1258-1263.

Oliveira L, L Malabarba \& P Majluf. 1999. Variação geográfica em crânios do lobo-marinho sul-americano Arctocephalus australis (Zimmermann, 1783) das populações do Brasil e Peru. Comunicações do Museu de Ciências e Tecnologia da PUCRS 12: 179-192.
Oliveira L, E Hingst-Zaher \& J Morgante. 2005. Size and shape sexual dimorphism in the skull of the South American fur Seal, Arctocephalus australis (Zimmermann, 1783) (Carnivora: Otariidae). The Latin American Journal of Aquatic Mammals 4(1): 27-40.

Oliveira L, J Hoffman, E Hingst-Zaher, P Majluf, M Muelbert, J Morgante \& W Amos. 2008. Morphological and genetic evidence for two evolutionarily significant units (ESUs) in the South American fur seal, Arctocephalus australis. Conservation Genetics 9: 1451-1466.

Page B, J McKenzie, M Sumner, M Coyne \& S Goldsworthy. 2006. Spatial separation of foraging habitats among New Zealand fur seals. Marine Ecology Progress Series 323: 263-279.

Pastor P \& A Aguilar. 2003. Reproductive cycle of the female Mediterranean monk seal in the western Sahara. Marine Mammal Science 19(2): 318-330.

Pavés H. 2008. Conducta reproductiva, mortalidad neonatal y tendencia poblacional de una agrupación reproductiva del lobo fino austral (Arctocephalus australis, Zimmermann, 1783) en la Isla Guafo, Chiloé, Chile. Tesis de Grado, Doctorado en Ciencias, mención Sistemática y Ecología, Facultad de Ciencias, Universidad Austral de Chile, Valdivia, $198 \mathrm{pp}$.

Pavés H \& R Schlatter. 2008. Patrones reproductivos del lobo fino austral, Arctocephalus australis (Zimmermann 1783) en la Isla Guafo, Chiloé, Chile. Revista Chilena de Historia Natural 81(1): 137-149.

Pavés H, R Schlatter \& E Espinoza. 2005. Patrones reproductivos del lobo marino común, Otaria flavescens (Shaw 1800), en el centro-sur de Chile. Revista Chilena de Historia Natural 78(4): 673-686.

Pitcher K, V Burkanov, D Calkins, B Le Boeuf, E Mamaev, R Merrick \& G Pendleton. 2001. Spatial and temporal variation in the timing of births of Steller sea lions. Journal of Mammalogy 82(4): 1047-1053.

Riedman M. 1990. The pinnipeds. seals, sealion, and walruses, 439 pp. University of California Press, Berkeley.

Sielfeld W. 1983. Sistemáticas y descripciones, Género Otaria Perón, 1816. En: Sielfeld W (ed). Mamíferos marinos de Chile, pp. 38-49. Ediciones Universidad de Chile, Santiago.

Sielfeld W. 1999. Estado del conocimiento sobre conservación y preservación de Otaria flavescens (Shaw 1800) y Arctocephalus australis (Zimmermann 1783) en las costas de Chile. Estudios Oceanológicos 18: 81-96.

Soto K, A Trites \& M Arias-Schreiber. 2004. The effects of prey availability on pup mortality and the timing of birth of South American sea lions (Otaria flavescens) in Perú. Journal of Zoology, London 264: 419-428.

Stenson G, R Myers, M Hammill, I-H Ni, W Warren \& M Kingsley. 1993. Pup production of Harp Seals, Phoca groenlandica, in the Northwest Atlantic. Canadian Journal of Fisheries and Aquatic Sciences 50: 2429-2439. 
Temte J. 1993. Latitudinal variation in the birth timing of captive California sea lions and other captive North Pacific pinnipeds. Fishery Bulletin 91: 710-717.

Temte J. 1994. Photoperiod control of birth timing in the harbour seal (Phoca vitulina), Journal of Zoology, London 233: 369384.

Testa J. 2002. Does predation on neonates inherently select for earlier birth? Journal of Mammalogy 83(3): 699-706.

Thompson D, C Duck, B McConnell \& J Garrett. 1998. Foraging behaviour and diet of lactating female southern sea lions (Otaria flavescens) in the Falkland Islands. Journal of Zoology, London 246: 135-146.

Thompson D, S Moss \& P Lovell. 2003. Foraging behaviour of South American fur seals Arctocephalus australis: extracting fine scale foraging behaviour from satellite tracks. Marine Ecology Progress Series 260: 285-296.

Trites A. 1992. Reproductive synchrony and the estimation of mean date of birth from daily counts of Northern fur seal pups. Marine Mammals Science 8(1): 44-56.
Trites A \& G Antonelis. 1994. The influence of climatic seasonality on the life cycle of the Pribilof northern fur seal. Marine Mammals Science 10(3): 311-324.

Túnez I, D Centro, L Cappozzo \& M Cassini. 2006. Geographic distribution and diversity of mitochondrial DNA haplotypes in South American sea lions (Otaria flavescens) and fur seals (Arctocephalus australis). Mammalian Biology 72: 193-203.

Túnez I, H Cappozzo, H Pavés, D Albareda \& M Cassini. 2013. The role of Pleistocene glaciations in shaping the genetic structure of South American fur seals (Arctocephalus australis). New Zealand Journal of Marine and Freshwater Research 47: 139-152.

Vila A. 1991. Reproducción sincronizada y éxito reproductivo en las hembras del león marino sudamericano (Otaria flavescens). Tesis de Licenciatura, Facultad de Ciencias Exactas y Naturales, Universidad de Buenos Aires, Buenos Aires, $87 \mathrm{pp}$.

Zar J. 1999. Biostatistical analysis, 663 pp. Prentice Hall, Upper Saddle River.

Received 4 March 2015 and accepted 28 January 2016

Associate Editor: Maritza Sepúlveda M. 